\title{
Investigating Cooperative Learning Model Based on Interpersonal Intelligence on Language Learners Skill to Write Article
}

\section{Sutarman}

Universitas Pendidikan Indonesia, h_sutarman74@yahoo.com

Dadang Sunendar

Universitas Pendidikan Indonesia, dadangsunendar@gmail.com

Yeti Mulyati

Universitas Pendidikan Indonesia, yetimulyati@upi.edu

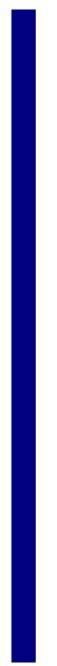

\begin{abstract}
This study aims to investigate and create a writing learning process that can generate both motivation and results from writing activities. The effectiveness of this model can be seen from students' improvement both the quality of the process and the results of writing learning. Based on preliminary study, this study found a number of data about writing learning. The findings covered students' low writing ability, their learning was still results-oriented rather than process, the learning approach is individual and has not optimized the potential of student interaction and collaboration, and the was only one draft as a product. To overcome the issues mentioned, this study proposes the model of cooperative learning based on interpersonal intelligence. The study applied quasi-experimental, with control groups and experimental groups given pretests and posttests. This study found that there was a significant increase in students' article writing ability. Their development in writing ability can be seen from aspects of content, organization, language, writing mechanics. In terms of the principle content of interpersonal skills, they experienced a significant increase. The implication of this study is to enable language teachers to deliver writing skill teaching to their language learners especially in their article writing.
\end{abstract}

Keywords: cooperative learning, interpersonal intelligence, writing article, learning process, learning model

\section{INTRODUCTION}

The world continues to grow and change very rapidly. It has brought us at an era the socalled the fourth generation of industrial revolution 4.0. Every aspect of life including education will experience the change into a better condition. Educators need to consider

Citation: Sutarman, Sunendar, D., \& Mulyati, Y. (2019). Investigating Cooperative Learning Model Based on Interpersonal Intelligence on Language Learners Skill to Write Article. International Journal of Instruction, 12(4), 201-218. https://doi.org/10.29333/iji.2019.12413a 
several changes that this revolution brings to the classroom (Shahroom, \& Hussin, 2018). Teachers are responsible to prepare their students to learn a number of skills or abilities that make strive in this era. In order to deal with the challenging era, there are at least five skills or abilities that are crucial for students. These skills entail the ability to think critically, creatively and innovatively, the ability to communicate, the ability to collaborate, and confidence. In order to realize the leadership of the five skills above, the world of education must take this vital role. All of these can be realized through an integrated process in the learning process.

Teachers are hailed as front liners in education and serve as the spearhead in the teaching and learning process. To meet the demand and challenges of industrial generation 4.0, they need to prepare and build their capacity (Hussin, 2018). They must be able to optimize their central role through various innovations in education and learning. Their contribution can be in the form of selection or search of learning models that are able to develop their students' five skills mentioned above. In the language teaching field, Indonesian language and literature teacher must be able to find alternative learning models that are capable of nurturing students' language-skilled and developing their five skills needed to compete in the era generation 4.0 industry.

In language teaching, there are four skills, namely listening, speaking, reading and writing. Out of four language skills, writing is a skill that is considered to be the most complex or has a fairly high level of difficulty. This is according to the findings Muslim (2014) students nowadays have very little interest in writing which is so important to fulfil the education requirements. This may be due to technology progress which has its negative effect on students' skills of writing because of the availability of ready-made assignments. Moreover, teachers have adopted the belief that writing is a kind of communication; this has led them to focus on the subject itself and overlook the incorrect style of writing. Feeling that students have no inclination to writing due to their weakness in it has been the impetus for the researcher to do the current study.

Writing difficulties among students have been discussed by various experts in language teaching. This skill has been daunting for students learning both their language or foreign language (Phakiti \& Li, 2011; Fareed, Ashraf, \& Bilal, 2016). In the Indonesian context, Nurgiyantoro (1995) and Alwasilah (1994), for example, admit that writing skills are more difficult to master compared to other three language skills, even though by native speakers. To be a skilful writer, it requires mastery of various linguistic elements and the information or knowledge they learn that will serve as the content of the writing. Likewise, Iskandarwassid and Sunendar (2008), said that compared to three other language skills writing skills are more difficult to master even by the speakers of the relevant linguists. Low writing skills among students indicate that the writing learning process at every level of education has not achieved optimally. This also implies the process of learning has a number of problems that must be solved and they required alternative solutions. Language teachers and researchers have paid attention to the process of writing for the students to overcome their writing difficulties (O'Neill \& Gravois, 2017), (Bayat, 2014), (Alodwan, T. A \& Ibnian, 2014). To deal with the issue, various efforts should be investigated. This study tries to examine the existing problems 
and plans to implement a pattern of actions that are expected to overcome students problems in the learning process of writing.

Writing difficulties have been investigated by language researchers. The difficulties come in many forms like learning process, structure, vocabularies and others. Studies conducted by Dumitrescu, et al. (2015), Rakedzon and Baram-Tsabari (2017), Huang, Oppenheimer et al. (2017), Steinlein et al., Cooney et al. (2018) reported that writing difficulties happened in language classes in their countries. Students learning writing skill experienced difficulties to achieve writing skill in several countries like Israel, Romania, USA and Taiwan. This problem also happens in Indonesia. Based on a preliminary study conducted in three junior high schools in Sumedang District, West Java Province, Indonesia, there were problems. They related to the existing writing learning process that had been implemented on in school. They can be identified specifically including 1) lack of feedback from peers or fellow students, (2) lack of students' potential for cooperation in writing, (3) lack of emphasis on process and (4) lack student interaction as the subject of learning. They have caused students' low writing process and results, especially in writing articles text. These findings confirm other previous studies on the causes of writing skill problem for students in language classes across the globe (Fadda, 2012, Alfaki, 2015).

Language teaching has developed and applied several approaches and methods to improve students' achievement in language learning. One of the methods used in learning is cooperative learning model. This model has attracted language teachers to try to implement in their teaching and learning process. Likewise language researchers have investigated this model in language teaching (Duxbury \& Tsai, 2010); (Zhang, 2010); (Gagne, N; Parks, 2013); (Altamimi \& Attamimi, 2014); (Motaei, 2014); (Chukwuyenum, AN., Nwankwo, E., Toochi, 2014); (Istiara \& Lustyantie, 2017); (Karim, K., \& Nassaji, 2018). The effectiveness of the model has also been scrutinized to boost both students' academic skill in terms of language skill achievement and social skill in terms of ability to work in a group (Orprayoon, 2014). The cooperative learning model is deemed to offer the promising learning model in the $21^{\text {st }}$ century for language teaching since it suits the need to nurture students skill in communication and collaboration ( Esai \& Mahbib, 2015).

Language researcher is also interested to investigate multiple intelligence role in language learning. Particularly, interpersonal intelligence has led several researchers to investigate its role in language learning (Hajebi, Abbas, Taheri, \& Noshadi, 2003); (Behjat, 2012); (Mobashshernia, R, Aghazadeh, 2018). It may have a correlation and contribute to student achievement in language learning. Students achievement in the test has been investigated to ensure the contribution of interpersonal intelligence in language learning (Behjat, 2012). This intelligence is also correlated with students' reading achievement. The higher the students' score in interpersonal intelligence, the higher their score in reading test (Mobashshernia, R, Aghazadeh, 2018). Studies on language learning using both cooperative learning and interpersonal intelligence have not been conducted intensively. This topic is under research in language learning especially for writing skill learning process. 
It is clear that language teaching always seeks to explore method and approach to improve students' achievement in learning language skills particularly writing skill. In the previous section, language teaching and cooperative learning model has been discussed. In addition, language teaching and its relationship in language teaching has also been highlighted. There is a lack of literature concerning learning writing skill using cooperative learning model and based on interpersonal intelligence. Language researchers have not spent their focus to investigate both concepts that are the cooperative learning model and based on interpersonal intelligence in learning writing skill. This gap should be filled. There is a need to investigate this research gap.

With these issues in mind, this study tries to investigate the cooperative learning model which is based on interpersonal intelligence in learning to write an article. To be specific this study sought to explore whether cooperative learning models with the values of interpersonal intelligence influence students' process and results in learning writing an article. In addition, peer interaction between students in the writing learning process to stimulate a model of collaboration in completing draft writing with several changes or revisions was also investigated. In other words, there is a multi-draft in the learning process by getting a number of inputs from fellow students and teachers in producing an article.

\section{REVIEW OF LITERATURE}

The learning model proposed in this study attempted to combine a number of theories, particularly those related to cooperative learning models from Slavin (2015), The Writing Process from Tompkins and Hoskisson (1991), and the theory of interpersonal intelligence proposed by Gardner Theory (1983), Armstrong (1985) and Yaumi (2012).

\section{Cooperative Learning Model}

Cooperative learning model has been the burning issue in the educational enterprise. It offers several benefits to boost students' learning. Based on the findings from NavarroPablo and Gallardo-Saborido (2015), Gillies et al. (2016), Prata et al (2019) cooperative learning model is recognized as an effective learning model and sound pedagogical approach to promote and socialize learning among students in any level of education. This model allows the learner to collaborate to achieve the shared goal and work together to achieve the goal that they cannot achieve if they work individually. Cooperative learning according to Slavin (2015) emphasizes learning and works in small groups collaboratively with members from four to six people, with heterogeneous group structures. It is more than just group learning or group work because it has compelling structure and tasks that are cooperative, allowing open interaction and effective relationships between group members. In cooperative learning, students will find and understand difficult concepts easier since they can discuss each other's problems with their friends (Slavin, 1995). It can improve student learning towards better, helping attitude in some social behaviour.

In an effort to implement cooperative learning model, teachers' play a pivotal role in promoting cooperation among students. They establish cooperative learning 
experiences for their learners in their classrooms. Their roles include structuring the groups and the tasks so that students know and grasp what they are expected to do and how they are expected to behave in a particular learning situation. Another role requires teachers to actively promote student interactions during small group discussions. By doing this, teachers show their role to help students to interact and work together not only to learn from each other but also to fulfil responsibility for the mission they have to accomplish and the decisions they have to make (Gillies, 2016).

Thus, it can be concluded that cooperative learning is learning in heterogeneous groups and encourages students to work together in maximizing their own learning and learning with their friends to achieve common goals. Johnson \& Johnson (Khuzaemah, 2012) outlines the basic components of cooperative learning, as follows.

a. Positive inter-dependent, so that students in the group really depend on each other positively clearly.

b. Face-to-face promotive interaction, all group members face to face in learning so that they engage in dialogue and develop efficient communication.

c. Individual accountability refers to understanding individual responsibilities and being accountable for individual tasks to achieve group goals.

d. Appropriate use of interpersonal skills is to develop various useful skills in interpersonal relationships in groups such as criticizing the ideas of others.

e. Group analysis, groups that continue to process their functions at this time to develop the effectiveness of their groups for the future.

There are several studies reporting the implementation of cooperative learning in language teaching. Elementary school students were enthusiastic and performed better in their language skills after they involved in cooperative learning model (Gagne, N, Parks, 2013). Istiana (2017) investigated the use of cooperative learning model in learning writing skill for the essay. The findings show that students writing skill improved after they involved in cooperative learning model (Istiara \& Lustyantie, 2017). Another skill like speaking skill improvement and its relationship with the cooperative learning model have been reported. Students showed improvement in their speaking skill performance after they were introduced with the cooperative learning model (Altamimi \& Attamimi, 2014). Motaei (2014) reported that students performed better after they used cooperative learning model in general English. Foreign language anxiety has been the issue that language teachers want to solve. Duxbury\&Tsai (2010) applied cooperative learning model to overcome language learning anxiety. Students show confidence in language learning after they involved in the cooperative learning model.

Cooperative learning model offers many benefits for language teachers and learners. A study by Zhang (2010) explore in details the benefits of cooperative learning model in a language class. The study reported that students performed well in academic skill and social skill. In Nigeria, conducted studies on cooperative learning model to improve students achievement in a language class. Students performed well in their language 
skills after they participated in a cooperative learning model (Chukwuyenum, AN., Nwankwo, E., Toochi, 2014). The effectiveness of the model has also been scrutinized to boost both students' academic skill in terms of language skill achievement and social skill in terms of ability to work in a group (Orprayoon, 2014). The cooperative learning model is deemed to offer the promising learning model in the $21^{\text {st }}$ century for language teaching since it suits the need to nurture students skill in communication and collaboration (Esai \& Mahbib, 2015).

\section{Interpersonal Intelligence}

Bainbridge argues, in a popular sense, intelligence is often defined as a general mental ability to learn and apply knowledge in manipulating the environment, as well as the ability to think abstractly (Yaumi, 2012). In the same vein, Armstrong (2013) suggests that interpersonal intelligence is the ability to understand and make differences in mood, intent, motivation, and feelings towards others. This can include sensitivity to facial expressions, voice and body movements. Other definitions of intelligence include the ability to adapt to the new environment or current environmental changes, to evaluate and assess, to understand complex ideas, to think productively, to learn quickly, to learn from experience, and to understand relationships (Fritz in Yaumi, 2012). Binet in Yaumi (2012) complements that the intelligence in it always contains the following three components. First, the ability to direct thoughts and actions. The second is the ability to change the direction of thoughts or actions. Third, the ability to criticize one's own thoughts and actions.

Despite the fact that there are pro and contradictions around the concept of intelligence, there is at least a common minimum requirement to say something is a form of intelligence. p. 11). It entails the ability to solve the problem which enables an individual to solve his existing problem (Gardner in Yaumi, 2012). In relation to interpersonal intelligence, Lwin et al. (2008); Arnaldi, (2014) suggests that interpersonal intelligence is the ability to connect with people around us. It refers to the ability to understand and predict other's feelings, temperaments, moods, intentions, and desires. It requires the ability to respond properly to that circumstance. It is this intelligence that allows us to build intimacy, influence, leadership, and relationships with society. In addition, Lwin et al. (2008) emphasize that interpersonal intelligence is not something that is born with you, but rather something that must be developed through coaching and learning, just like other intelligence.

Thus, it can be said that interpersonal intelligence is the ability to understand people's thoughts, attitudes, and behaviours. It can also be interpreted as the ability to perceive and distinguish other's moods, intentions, motivations, and desires of others, as well as the ability to respond appropriately. Interpersonal intelligence in this study can be identified the basic principles of values contained in the main skills of interpersonal intelligence. The values include (1) the ability to empathize with others, (2) the ability to organize a group of people towards a common goal, (3) the ability to recognize and read the minds of others, and (4) the ability to make friends or establish contacts (Yaumi, 2012). 
Language researcher is also curious to scrutinize the interpersonal intelligence role in language learning. The findings showed that the higher the students' interpersonal intelligence, the higher their reading score. It can be very determinant in language learning (Mobashshernia, R; Aghazadeh, 2018). Behjat studied interpersonal intelligent in a language class. The study aimed to find out whether interpersonal intelligence was significant in relation to students achievement in grammar and reading skill. Findings showed that interpersonal intelligence had a higher relationship with students achievement (Behjat, 2012). Vocabulary learning has also been related to interpersonal intelligence. Hajebi et al (2003) investigated students' vocabulary learning and its relationship with interpersonal intelligence. Findings showed that students enhanced their vocabulary achievement in language learning.

The format model is to apply the elements or values mentioned above in the context of writing learning as well as in the results of writing. The target is to improve students' quality of the writing learning process and at the same time instilling the values of interpersonal intelligence. It can be expected that the quality of the process and the results of writing learning are more optimal. Through the cultivation of interpersonal intelligence in the process of writing learning, students are expected to be able to carry out writing activities with full interest, care, cooperation, and optimal multi-directional interactions. They can build themselves through communication and interaction that is full of empathy, both with colleagues in the learning process and indications of human interest in written content.

To write a piece of article, there are several steps that can be implemented based on cooperative learning model using interpersonal intelligence. First, teachers inform their learning objectives and perform apperception. Second, they deliver information by providing an example of an article using the theme of social life featuring interpersonal intelligence values. Third, they organize students in group learning. Fourth, they guide students to accomplish the assignment. Fifth, they evaluate students' process and product. In the evaluation stage, they along with students assess each article to determine the best article made by the group in the class. The last stage, they reward a group of students that perform the best in writing an article.

\section{Article Writing Skill Criteria}

Writing is one of the language skills that language learners learn to convey meaningful messages and to communicate what they think in different contexts (Kheider, 2016). Moreover, this skill allows language learners to demonstrate and produce knowledge and improve language learners' learning ability. Students' achievement finally helps the school to promote their success in its educational activities (Klein, Arcon, \& Baker, 2016). However, language learners may find writing skill difficult to achieve since it requires Knowledge mastery concerning grammar, punctuation, spelling and sentence structure. They also need to deal with the process of writing like planning, drafting, translating and revision (Graham, Early, \& Wilcox, 2014; Prata, et all., 2019).

In this study writing skill that students need to achieve refers to scientific writing. This scientific writing may bring challenges to overcome by students. To be able to write a 
scientific article is a requirement to be part of the scientific community in order to share and gain knowledge especially for second language learners (Leki, Cumming, \& Silva, 2010; Paltridge, 2004). Scientific writing follows the stages of IMRAD that is Introduction, Method, Result and Discussion. Learning this pattern and stages should also be coupled with the knowledge of an article structure and the use of word and sentence structure. The scientific article is formal in nature and frequently uses technical language to address the professional audience with a high educational background (Rakedzon \& Baram-Tsabari, 2017).

In this study, writing skill that students need to master refers to writing skill coming from simple observation. The concept of the article in this study refers to the concept of an article from American Journalists in http://www.gaulislam.com (writing-scientificpopular). The term article for writing contains opinions, attitudes, or subjective stand regarding the problem being discussed by delivering evidence that supports the opinion. In a broader sense, Pranata in Andriyansah (2014, p. 5) describes the article as a paper or essay, a nonfiction essay, an indefinite essay, that aims to convince, educate, or entertain. It uses the means of delivery like newspapers, magazines, and other media. In the same vein, Sumadiria (2011, p. 1) defines the article is freelance writing that contains someone's opinion that thoroughly explores a particular problem that is actual, and or controversial with the aim of telling (informative), influencing and convincing (persuasive argumentative), or entertain a (recreational) audience. Technically, journalistic articles are one form of opinion contained in newspapers or magazines.

Based on a number of definitions above, in a nutshell, the article can be said as a complete piece of writing that explores actual topics and problems with the aim of informing, convincing/influencing, or entertaining, published in newspapers, magazines, and others. To meet the requirement of an article, a piece of writing should comply with the composition and organization of articles. The principles of an article are as follows (Sumadiria, 2011, p. 59).

a. Unity

The principle of unity includes three elements, namely: nature, content, and purpose. This means that whatever is discussed in an article must not come out of the elements of unity. Unity stresses that all the articles are in one entity when viewed from their nature, content, and purpose. It indicates that the articles are arranged in one set of languages. focus on the issues discussed.

b. Coherence

The principle emphasizes that the problem should be described in a way where it flows clearly from one sentence to another or from one paragraph to another. Words that specifically indicate the existence of coherence include: thus, therefore, so, as a result, for example, the next step, but, then, maybe, and in short.

c. Emphasis

The emphasis means that an author must put pressure on certain parts that are considered important or should receive special attention from the reader. It allows the reader to find a thesis in the article. The thesis, in this case, is the conclusion of the main opinion of the entire article description. 
There are several important components that can be used as parameters in writing an article. These parameters include:

a. Content of an article, it should carry breadth and depth of the content or information

b. Language, it should meet the grammatical accuracy and effectiveness.

c. The organization, it should feature regular and logical presentation of ideas.

d. Writing style, the article should feature creativity in displaying uniqueness, novelty, and writing development approach.

e. Spelling and punctuation, accuracy and accuracy of punctuation spelling, letter writing, word writing, term writing, and number writing.

f. Elements of popular scientific text, it applies a simple presentation of an idea so that it is easy to understand by the reader (Jauhari, 2013).

\section{METHOD}

\section{Respondents}

This research was conducted to investigate a cooperative learning model in writing article in junior high school. It took place in Sumedang District State Junior High School, Sumedang Regency, Indonesia. This study selected a sample of schools randomly on the basis of their similarities. Their similarities in this study were divided into two categories namely: their decision to accept a new student based on the result of the National Examination determined by the school and their seasoned Indonesian language teachers. Each school participating in the study was selected and determined by two groups of students, one group for the control class (30 students) and other for the experimental class (30 students). Both groups received different treatment. Control group was taught using conventional way and the experimental group was taught using cooperative learning based on interpersonal intelligence. Data collected in the study include students 'writing ability, in this case, their article, their learning process, and their responses to writing learning models based on interpersonal intelligence. The first data was gained from observation and questionnaire given to students. To gain second data, formative and summative test was applied. The third data was taken from the scheme of model implementation. This scheme refers to the steps implemented in learning to write an article. The activities were based on four principles of interpersonal intelligence proposed by Yaumi (2012). In addition, each sentence in students' article was analyzed to investigate the values or indicator of interpersonal intelligence. Their explicit written interpersonal intelligence values were expected to benefit their learning process and outcomes.

\section{Instruments}

This study employed several instruments. Learning model instruments were outlined in the form of learning plans, formative and summative test. Students were asked to write an article with the topics available or determined by the teacher. The topics have one thing in common since they express their care to the people surrounding. Why the topics 
should discuss social care? This was done to trigger and stimulate students' interpersonal intelligence so that they express their care in their article. Other two instruments include students' article and questionnaire. The learning model instrument was outlined in the form of a learning plan that integrated the existing principles in the theory of cooperative learning models and interpersonal intelligence. The integration was illustrated in the steps of the learning process for article writing. The three basic foundations that inspire the learning process are cooperation, collaboration, and the growth of care and empathy toward other's thought.

The study also applied two instruments namely test and questionnaire. Formative and summative test instruments for students 'writing skills were used to evaluate their improvement in writing articles. The assessment was based on the rubric that was stated in the previous section. Questionnaire instrument was given to students after they had undergone the learning process to investigate their perception of cooperative learning models based on interpersonal intelligence. This was done to determine their attitude and acceptability towards the learning model they participated.

\section{Procedures}

This study used a quasi-experimental design because it aimed to examine the effectiveness of cooperative learning models based on interpersonal intelligence, with the experimental group and the control group was given pretests and posttests (Creswell, 2014). It sought to determine the extent of the effectiveness of this model in improving students' article writing.

\section{Data analysis}

This study gained two types of data namely: students' ability to write articles and their responses to the cooperative learning model. The data analysis was done using two methods, namely qualitative descriptive analysis and quantitative analysis. Qualitative descriptive analysis was used to analyze students' responses on a questionnaire related to their learning process. In addition, it describes language phrases or sentences that student-produced in their articles to represent the principles of interpersonal intelligence.

On the other hand, quantitative analysis was used to determine the effectiveness level of the learning model being tested. The level of learning model effectiveness was shown through a comparison of students' average learning outcomes. The analysis technique used is paired sample t-test because the obtained data comes from the measurement process in one sample group which was done twice, namely pre-test and post-test. This study employed the Statistical Package for Social Sciences (SPSS) statistical program package 12 to process and analyze quantitative data.

\section{FINDINGS}

This study was aimed at investigating cooperative learning model based on interpersonal intelligence in learning article writing. In this section, the findings of the research will be described. The findings include control group ability to write articles, experimental group's ability to write an article, interpersonal intelligence values found in student 
articles, and their responses to cooperative learning models based on interpersonal intelligence. The control group was given an evaluation to write an article. This study measured and analyzed their performance. The results of their article writing ability are as follows:

Table 1

Control Group's Article Writing Ability

\begin{tabular}{lll}
\hline & s & \\
\hline & Pretest & Postest \\
\hline $\mathrm{N} \quad$ Valid & 30 & 30 \\
Missing & 0 & 0 \\
Mean & 69.13 & 71.10 \\
Std. Error of Mean & 1.781 & 1.656 \\
Median & 68.00 & 67.00 \\
Std. Deviation & 9.755 & 9.068 \\
Variance & 95.154 & 82.231 \\
Minimum & 50 & 54 \\
Maximum & 87 & 89 \\
\hline
\end{tabular}

From the table, it can be seen that the average value of pretest is 69.13 and posttest 71.10. This data shows an increase in the control group's ability to write articles by $1.97 \%$. On the other hand, the experimental group was given pre-test, received treatment of a cooperative learning model based on interpersonal intelligence, and at the end they took posttest. Their performance can be seen in the following results.

Table 2

Experimental Group's Article Writing Ability

\begin{tabular}{lll}
\hline & s & \\
\hline $\mathrm{N} \quad$ Valid & Pretest & Postest \\
$\mathrm{Missing}$ & 30 & 30 \\
$\mathrm{Mean}$ & 0 & 0 \\
Std. Error of Mean & 57.30 & 68.17 \\
Median & 1.829 & 1.739 \\
Std. Deviation & 55.00 & 69.50 \\
Variance & 10.018 & 9.527 \\
Minimum & 100.355 & 90.764 \\
Maximum & 43 & 48 \\
\hline
\end{tabular}

Based on the above table, their average pretest score is 57.30 and post-test 68.17 . This data shows an increase in their ability to write articles by $10.87 \%$. In the experimental class, they had produced articles after they received treatment. Their articles were analyzed in relation to several aspects namely: content, organization, language, and writing mechanics. The analysis was also applied to expressions containing values from the principle of interpersonal intelligence. As adapted from Gardner's (2013), Yaumi (2012), and Armstrong (2013) theory, there are four principles that characterize the value of interpersonal intelligence in terms of their ability to: (1) empathize with others, 
(2) organize a group of people towards a common goal, (3) recognize and read other people's thoughts, and (4) make friends or establish contacts.

The findings based on the results of the student questionnaire about the impact of model application are as follows: a total of 24 students (80\%) answered importantly and some answered very important. This shows that most students begin to realize the importance of writing activities, a total of 26 students $(88 \%)$ answered increasing. This means that most students really have increased awareness about writing skills. The rest, 4 students answered simply. A total of 29 students (97\%) answered happily because they felt fully involved, such as a race, and there were prizes. A total of 29 students (97\%) said they were happy because at the time the writing was corrected his friend also corrected a friend's article writing. So, full of enthusiasm, confidence arises because they feel they are trusted, and unconsciously students are trained to be skilled in critical thinking.

Based on the finding and analysis of the data above, the results of the research are significant in improving students' ability to write articles. This can be seen from the differences in the comparison of the average value of articles between the control group and the experimental group after the two groups were given pretests and posttests. It can be said that cooperative learning models based on interpersonal intelligence are very effective to improve their ability to write articles.

Students who joined the experimental group have produced in their articles aspects of language phrases and sentences that describe the four principles in interpersonal intelligence. Likewise, the results of questionnaires to the experimental group students after learning was completed, a very positive response was obtained due to the instructional impact they received. This model was able to develop the skills needed for the younger generation to face the generation 4.0 industrial revolution.

\section{DISCUSSION}

Based on the statistical findings, the experiment group in writing article was better than the control group. This happened because in cooperative learning students not only learned in the group but there was also a structure of motive and an assignment which was cooperative in nature. This allows open interaction and effective relation between group members. In cooperative learning, it was easier for students to find out and discuss difficult concepts to understand since they could discuss with their peers. In this study, students were grouped and were encouraged to cooperate to optimize their learning and to achieve their learning objectives. They were assigned to write article in a simple form and they review and revise their article. This enabled them to experience peer review and revision this learning method allowed students to improve their writing skill in producing an article.

This study is aimed at investigating cooperative learning model to improve students writing skill. This effort was made to overcome students' difficulties in writing an article. Difficulties in writing skill have been the center of the issue among language researchers. These findings confirm other previous studies on the causes of writing skill problem for students in language classes across the globe (Alfaki, 2015) ; (Fadda, 2012). This problem has been daunting for students learning both their language or 
foreign language (Fareed et al., 2016) ; (Phakiti \& Li, 2011). Teachers need to pay attention to writing skill learning process to ensure their student's achievement in writing skill. The process of writing needs to be taken into account to ensure students achievement and to overcome their writing difficulties (O'Neill \& Gravois, 2017); (Bayat, 2014); (Alodwan, T. A; Indian, 2014).

This study shows that cooperative learning model based on interpersonal intelligence contributed to students' achievement in writing article. The student showed their enthusiasm in learning writing and this conformed study by Gagne (2013. Students showed improvement in writing skill after they participated in a cooperative learning model. This echoed the previous studied by Istiana (2017) which investigated the use of cooperative learning model in learning writing skill for the essay. The findings show that students writing skill improved after they involved in cooperative learning model (Istiara \& Lustyantie, 2017). Another important thing, students showed their confidence in learning writing. This is in line with the study by Motaei (2014). It reported that students performed better after they used cooperative learning model in general English. Students show confidence in language learning after they involved in cooperative learning model (Duxbury \& Tsai, 2010).

Cooperative learning model offers many benefits for language teachers and learners in this study. This supports a study by Zhang (2010) which explores in details the benefits of cooperative learning model in a language class. The study reported that students performed well in academic skill and social skill (Zhang, 2010). This study also foud a similar thing with study In Nigeria, Chukwuyenum (2014). It conducted studies on cooperative learning model to improve students achievement in a language class. Students performed well in their language skills after they participated in a cooperative learning model (Chukwuyenum, AN., Nwankwo, E., Toochi, 2014). This study also found that students showed both academic skill and social skill in group work. This is similar to the study by Orpryon (2014). It goes without saying that Cooperative learning model is deemed to offer the promising learning model in the $21^{\text {st }}$ century for language teaching since it suits the need to nurture students skill in communication and collaboration ( Esai \& Mahbib, 2015).

This study found that students showed their interpersonal intelligence in their writing process. These findings confirmed the previous study by Mobashshernia (2018). It investigated the relationship between interpersonal intelligence and reading skill achievement. The findings showed that the higher the students' interpersonal intelligence, the higher their reading score. It can be very determinant in language learning (Mobashshernia, R; Aghazadeh, 2018). Behjat (2012) studied interpersonal intelligence in a language class. The study aimed to find out whether interpersonal intelligence was significant in relation to students achievement in grammar and reading skill. Findings showed that interpersonal intelligence had a higher relationship with students achievement (Behjat, 2012). This is in accordance with the analysis of the results of the questionnaire. A number of answers from the questionnaire were obtained including: (1) increasing motivation to write, (2) foster a critical attitude, (3) improving 
the ability to think critically, (4) the growth of confidence in writing, and (5) feel guided to appreciate something and learn to work together.

This finding is in line with a previous study conducted by Zuhairi (2016) stating that students used the more mental process to deal with writing challenges and complexity. For the cognitive aspect, students demonstrated this by memorizing, practising, revising during their writing article learning. In this study, the emphasis was given to social process and this is in line with a previous study conducted by Genlott \& Grönlund (2013) explaining that social process improves students' motivation and understanding on how to show care to others, collaborate, and interact. Students were able to develop themselves through communication and interaction characterized by empathy with their peers during the learning process. They also featured human interest in their article content. In other words, students accomplished tasks that would be checked and revised by their teacher.

\section{CONCLUSION}

Given the finding and analysis in the previous section, it was concluded that the application of cooperative learning models based on interpersonal intelligence proved to be very effective in improving the ability to write articles among junior high school students. In their article, students were able to feature values of the principles from interpersonal intelligence. Their responses to the use of this model were very positive. The implication of this study is to promote cooperative learning based on interpersonal intelligence in the process writing skill learning especially in promoting their critical reading, critical thinking and critical attitude. They can learn to apply to criticize when they conduct peer review of their friends' article. In a macro scale, this study supports literacy movement in the school since it promotes reading activities to search for information and use it for their writing activities. In addition, this study promotes interpersonal intelligence since it raises student care on their surroundings. This is achieved since the process and the outcome of learning is filled with interpersonal intelligence principles.

\section{REFERENCES}

Alfaki, I. M. (2015). University students' english writing problems: Diagnosis and remedy. Internasional Journal of English Language Teaching, 3(3), 40-52.

Alodwan, T. A. A., \& Ibnian, S. S. K. (2014). The Effect of using the process approach to writing on developing university students' essay writing skills in EFL. International Journal of Linguistic and Communication, 2(2), 147-163.

Alwasilah, A.Ch. (1994). Dari Cicalengka sampai Chicago: Bunga Rampai Pendidikan Bahasa. Bandung: Angkasa.

Andriyansah. (2014). Pintar menulis artikel; panduan praktis menulis ilmiah, non ilmiah, dan ilmiah populer. Bandung: Satu Nusa.

Armstrong, T. (2013). Kecerdasan multiple di dalam kelas. Jakarta: Indeks. 
Arnaldi, M. (2014). Four factor psychologies as executive function to increase the interest of learning. Procedia-Social and Behavioral Sciences, 112, 503-509. doi: 10.1016/j.sbspro.2014.01.1195.

Bayat, N. (2014). The effect of the process writing approach on writing success and anxiety. Educational Sciences: Theory \& Practice, 14(3), 1133-1141. doi: 10.12738/estp.2014.3.1720

Behjat, F. (2012). Interpersonal and intrapersonal intelligence: Do they really work in foreign-language learning? Procedia-Social and Behavioral Sciences, 32, 351-355. doi:10.1016/j.sbspro.2012.01.052.

Cooney, A., Eamon, D., \& Casey, D. (2018). Integrating reading and writing: Supporting students' writing from source. Journal of University Teaching \& Learning Practice, 15(5). Retrieved from https://files.eric.ed.gov/fulltext/EJ1200555.pdf.

Creswell, J. W. (2014). Research design: Qualitative, quantitative and mixed method approaches. London: Sage.

Chukwuyenum, A. N., Nwankwo, A. E., \& Toochi, U. (2014). Impact of cooperative learning on english language achievement among senior secondary school students in Delta State, Nigeria. Journal of Emerging Trends in Educational Research and Policy Studies, 5(7), 70-76.

Dumitrescu, C. I., Coman, M. L., \& Ioana-Claudia, N. (2015). Improving functional texts writing skills in English as a foreign language. Procedia-Social and Behavioral Sciences, 203, 168-172. doi: 10.1016/j.sbspro.2015.08.277.

Duxbury, J. G., \& Tsai, L. L. (2010). The effects of cooperative learning on foreign language anxiety: A comparative study of Taiwanese and American universities. International Journal of Instruction, 3(1), 3-18.

Fareed, M., Ashraf, A., \& Bilal, M. (2016). ESL learners' writing skills: Problems, factors and suggestions. Journal of Education \& Social Sciences, 4(2), 83-94. doi: $10.20547 /$ jess0421604201.

Fadda, H. A. (2012). Difficulties in academic writing: From the perspective of King Saud University postgraduate students. English Language Teaching, 5(3), 123-130. doi: 10.5539/elt.v5n3p123.

Gagne, N., \& Parks, S. (2013). Cooperative learning tasks in a grade 6 intensive ESL Class: Role of Scaffolding. Language Teaching Research, 17(2), 188-209. doi: $10.1177 / 1362168812460818$.

Gardner, H. (2013), Multiple intelligences. Jakarta: Dara Books.

Genlott, A. A., \& Grönlund, A. (2013). Improving literacy skills through learning reading by writing: The iWTR method presented and tested. Computers and Education. 67, 98-104. doi: 10.1016/j.compedu.2013.03.007. 
Gillies, R. M. (2016). Cooperative learning: Review of research and practice. Australian Journal of Teacher Education, 41(3), 39-54. doi: 10.14221/ajte.2016v41n3.3.

Graham, S., Early, J., \& Wilcox, K. (2014). Adolescent writing and writing instruc-tion: Introduction to the special issue. Reading and Writing: An Interdisciplinary Journal, 27(6), 969-972. doi: 10.1007/s11145-014-9497-0.

Haerudin, D. (2010). Model pembelajaran diskusi kelompok bernomor (DKB) dalam pembelajaran membaca pemahaman artikel berbahasa Indonesia (Unpublished doctoral dissertation). SPS UPI. Retrieved from http:((www.gaulislam.com(tulisanilmiah-populer).

Hajebi, M., Abbas, B., Taheri, S., \& Noshadi, M. (2003). The relationship between interpersonal intelligence, reading activity and vocabulary learning among Iranian EFL learners. International Journal of English Language \& Translation Studies, 6(1), 48-56.

Hussin, A. A. (2018). Education 4.0 made simple: Ideas for teaching. International Conference of Economic and Management Processes, 3, 92-98.

Huang, J. C. (2017). What do subject experts teach about writing research articles? An exploratory study. Journal of English for Academic Purposes. 25, 18-29.

Iskandarwassid dan Dadang S. (2008). Strategi pembelajaran bahasa. Bandung: PT Remaja Rasda Karya.

Istiara, F., \& Lustyantie, N. (2017). The influence of cooperatif learning model and critical thinking on essay writing skills (experiment study). World Journal of English Language, 7(2), 22-30. doi: 10.5430/wjel.v7n2p22

Jauhari, H. (2013). Terampil mengarang. Bandung: Pustaka Cendikia.

Esai A., \& Mahbib, U. K. (Oktober, 2015). Cooperative learning as an alternative approach to language learning in $21^{\text {st }}$ century: Research review. In International Association for the Study of Cooperation in Education (IASCE) Conference 2015 (pp. 1-17). Univerisity College Lillebaelt, Odense, Denmark.

Karim, K., \& Nassaji, H. (2018). The revision and transfer effects of direct and indirect comprehensive corrective feedback on ESL students' writing. Language Teaching Research, first online. doi: 10.1177/1362168818802469.

Klein, P., Arcon, N., \& Baker, S. (2016). Writing to learn. In C. MacArthur, S. Graham, \& J. Fitzgerald (Eds.), Handbook of writing research (pp. 243-256). New York: The Guilford Press.

Kheider, M. (2016). The use of cooperative learning strategies to enhance students' writting skill. (Unpublished doctoral dissertation). University of Biskra, Algeria.

Khuzaemah, E. (2012). Peningkatan kemampuan menulis karangan narasi melalui model pembelajaran kooperatif berorientasi kecerdasan spiritual (penelitian pengembangan di SMA negeri kabupaten Cirebon tahun pelajaran 2010(2011) (Unpublished doctoral dissertation). Bandung: SPS UPI Bandung. 
Leki, I., Cumming, A., \& Silva, T. (2010). A synthesis of research on second language writing in English. New York, NY: Routledge.

Lwin, M. dkk. (2008). Cara mengembangkan berbagai komponen kecerdasan. Jakarta: Indeks.

Muslim, I. M. (2014). Helping EFL students improve their writing. International Journal of Humanities and Social Science. 4(2), 105-112.

Altamimi, N. O. M., \& Attamimi, R. (2014). Effectiveness of cooperative learning in enhancing speaking skills and attitudes towards learning English. International Journal of Linguistics, 6(4), 27-45. doi:10.5296/ijl.v6i4.6114.

Mobashshernia, R., \& Aghazadeh, S. M. (2018). The relationship between the interpersonal intelligence and reading comprehension achievement of Iranian bilingual and multilingual EFL learners. International Journal of Research in English Education (IJREE), 3(3), 13-20. doi: 10.29252/ijree.3.3.13.

Motaei, B. (2014). On the effect of cooperative learning on general English achievement of Kermanshah Islamic Azad University students. Procedia-Social and Behavioral Sciences, 98, 1249-1254. doi: 10.1016/j.sbspro.2014.03.540.

Nurgiyantoro, B. (1995). Penilaian dalam pengajaran bahasa dan sastra. Yogyakarta: BPFE.

O’Neill, K. S., \& Gravois, R. (2017). Using a focus on revision to improve students' writing skills. Journal of Instructional Pedagogies, 19, 1-12.

Orprayoon, S. (2014). Effects of cooperative learning on learning achievement and group working behavior of junior students in modern french literature course. The Journal of Effective Teaching, 14(1), 80-98.

Oppenheimer, D., Zaromb, F., Pomerantz J. R., Wiliams, J. C., \& Park, Y. S. (2017). Improvement of writing skills during college: A multi-year cross-sectional and longitudinal study of undergraduate writing performance. Assessing Writing, 32, 12-27. doi: 10.1016/j.asw.2016.11.001

Navarro-Pablo, M., \& Gallardo-Saborido, E. J. (2015). Teaching to training teachers through cooperative learning. Procedia - Social and Behavioral Sciences. 180, 401-406. doi: 10.1016/j.sbspro.2015.02.136

Paltridge, B. (2004). Academic writing. Language Teaching, 37, 87-105. doi: $10.1017 / \mathrm{S} 0261444804002216$.

Phakiti, A., \& Li, L. (2011). General academic difficulties and reading and writing difficulties among Asian ESL postgraduate students in TESOL at an Australian University. RELC Journal, 42(3), 227-264.

Prata, M. J., Festas, I., Oliveira L. A., \& Veiga, F. H. (2019). The impact of a cooperative method embedded in a writing strategy instructional program on student 
engagement in school. Revista de Psicodidactica, 24(2), 145-153. doi: 10.1016/j.psicoe.2018.12.001.

Rakedzon, T., \& Baram-Tsabari, A. (2017). To make a long story short: A rubric for assessing graduate students' academic and popular science writing skills. Assessing Writing, 32, 28-42. doi: 10.1016/j.asw.2016.12.004.

Shahroom, A. A., \& Hussin, N. (2018). Industrial revolution 4.0 and Education. International Journal of Academic Research in Business and Social Sciences 8(9), 314319. doi: 10.6007/IJARBSS/v8-i9/4593.

Slavin, R. E. (1995). Cooperative learning, theory, research, and practice. Boston: Allyn and Bacon.

Slavin, R. E. (2005). Cooperative learning. Bandung: Nusa Media.

Slavin, R. E. (2015). Cooperative learning in school. International Encyclopedia of the Social \& Behavioral Sciences, 4, 881-886.

Steinlen, A. K. (2018). The development of German and English writing skills in a bilingual primary school in Germany. Journal of Second Language Writing, 39, $42-52$.

Sumadiria, H. (2011). Menulis artikel dan tajuk rencana; panduan praktis penulis \& jurnalis profesional. Bandung: Simbiosa Rekatama Media.

Tomkins, G. E., \& Hoskisson, K. (1991). Language arts: Content and teaching strategies. New York: Macmillan Publishing Company.

Yaumi, M. (2012). Pembelajaran berbasis multiple intelligences. Jakarta: Dian Rakyat.

Zhang, Y. (2010). Cooperative language learning and foreign language learning and teaching. Journal of Language Teaching and Research, 1(1), 81-83.

Zuhairi, A. (2016). The Indonesian Junior high school students' strategies in learning writing skill. Arab Word English Journal, 7(3), 385-393. 